\title{
ArcheoSciences
}

Revue d'archéométrie

\section{Some problems and potentials of the study of cupellation remains: the case of post-medieval Montbéliard, France}

Problèmes et perspectives à partir de l'étude des vestiges archéologiques issus de la coupellation : l'exemple du site de Montbéliard (France)

Marcos Martinón-Torres, Nicolas Thomas, Thilo Rehren and Aude Mongiatti

\section{OpenEdition}

\section{Journals}

\section{Electronic version}

URL: https://journals.openedition.org/archeosciences/948

DOI: 10.4000/archeosciences.948

ISBN: 978-2-7535-1597-0

ISSN: $2104-3728$

\section{Publisher}

Presses universitaires de Rennes

\section{Printed version}

Date of publication: 31 December 2008

Number of pages: $59-70$

ISBN: 978-2-7535-0868-2

ISSN: 1960-1360

Electronic reference

Marcos Martinón-Torres, Nicolas Thomas, Thilo Rehren and Aude Mongiatti, "Some problems and potentials of the study of cupellation remains: the case of post-medieval Montbéliard, France", ArcheoSciences [Online], 32 | 2008, Online since 31 December 2011, connection on 21 September 2021. URL: http://journals.openedition.org/archeosciences/948 ; DOI: https://doi.org/10.4000/ archeosciences.948 


\title{
Some problems and potentials of the study of cupellation remains: the case of post-medieval Montbéliard, France
}

\author{
Problèmes et perspectives à partir de l'étude des vestiges archéologiques issus \\ de la coupellation : l'exemple du site de Montbéliard (France)
}

\author{
Marcos Martinón-Torres*, Nicolas ThOMAs**, \\ Thilo Rehren*, and Aude Mongiatti*
}

\begin{abstract}
Bone-ash cupels are increasingly identified in medieval and later archaeological contexts related to the refining of noble metals in alchemy, assaying, jewellery or coin minting. These small finds may provide information on metal refining activities, the technical knowledge of different craftspeople, and the versatility of laboratory practices, which often differed from the standard protocols recorded in metallurgical treatises.

This paper is centred around a late $16^{\text {th }}$-early $17^{\text {th }}$ century cupel excavated in Montbéliard, France. The analytical study by optical microscopy, ED-XRF and SEM-EDS allows the cupel to be ascribed to the assaying of the silver content of an ore sample, which is supported by local historical and geological information. The manufacture of the cupel, made of a mixture of wood ash and bone ash, is also addressed, as well as the limited technical efficiency of the operation. This leads to a wider discussion of different recipes for the manufacture of cupels, documented historically and archaeologically, and involving the combination of various raw materials such as bone, wood ashes and clay. This variability raises interesting questions about the existence of diverse technical traditions, and the material properties and performance of different cupels in their specific contexts. In order to facilitate comparisons, we propose that the study of cupellation remains is most informative when it combines microscopy and microanalysis. The role of experimental approaches to these questions is also discussed.
\end{abstract}

Résumé : Les coupelles en cendres d'os sont de plus en plus nombreuses à être reconnues dans des fouilles médiévales ou modernes. Elles sont utilisées pour l'affinage de métal précieux par les alchimistes, les essayeurs, les orfevres ou encore les monnayeurs. Ces artefacts peuvent fournir des informations sur les techniques d'affinage, les savoir-faire et les pratiques de l'atelier qui souvent sont différentes des recettes et procédés décrits dans les textes métallurgiques. Cette étude concerne une coupelle de la fin du XVI siècle ou du début du XVII siècles découverte en fouille à Montbéliard (France). Les analyses, par microscopie optique, MEB-EDS, et ED-XRF permettent d'associer la coupelle à l'essai d'un échantillon de minerai de cuivre argentifere, hypothèse confirmée par l'étude des sources écrites et géologiques locales. La fabrication de la coupelle, faite d'un mélange de cendre de végétaux et de cendre d'os est également abordée comme les limites et l'efficacité de l'opération. Ces résultats mènent à une discussion plus large sur les différentes recettes de fabrication de coupelle grâce aux sources écrites et archéologiques qui indiquent des matières premières diversifiées comme la cendre d'os, la cendre de végétaux et la terre. Cette variabilité soulève des questions intéressantes sur l'existence de traditions techniques diverses ainsi que sur les propiétés et l'efficacité de ces coupelles. À des fins comparatives, nous concluons que l'étude de ces artefacts est plus efficace en associant la microscopie et la microanalyse. Enfin, le rôle des approches expérimentales à ces questions est également discuté.

Keywords: Assaying, Bone ash, Cupellation, Ore, Performance characteristics, Silver.

Mots clés : Argent, Cendre d'os, Coupellation, Efficacité, Essais, Minerai.

\footnotetext{
* Institute of Archaeology, University College London, 31-34 Gordon Square, London, WC1H 0PY. (m.martinon-torres@ucl.ac.uk)(th.rehren@ucl. ac.uk.)(a.mongiatti@ucl.ac.uk)

** Institut national de recherches archéologiques préventives (INRAP), Université Paris I Panthéon-Sorbonne, équipe d'Histoire des Techniques, UMR 8589, Laboratoire de médiévistique Occidentale de Paris (LAMOP). (nicolasthomas@noos.fr)
} 


\section{BACKGROUND}

Cupellation is a high-temperature metallurgical operation aimed at refining the noble metals contained in a larger metal matrix, normally dominated by lead. The metal is melted under oxidising conditions so that the lead is oxidised to litharge (lead oxide), which acts in two ways (Bayley 1991: 125): it oxidises any other base metals present, and it reacts with these metal oxides, forming fusible compounds. As a result, the noble metals, which do not react with oxygen or lead oxide, separate from the melt as a discrete button. Since the late Middle Ages, the small-scale counterpart of cupellation is carried out in thick, porous, ash-based vessels known as cupels (Rehren and Eckstein 2002). The ashes from calcined bone constitute the most typical cupel material, still in use today (although increasingly replaced by magnesia). The technical reason for this is that the mineral bone apatite does not react with the oxidised metals but mechanically absorbs them by capillary action, while the noble metal, sustained by its higher surface tension, settles on top, thus obtaining a neat separation (Rehren and Klappauf 1995) (Fig. 1).

Even though they are known from an increasing number of archaeological sites and primary written sources, cupels pose interesting questions that have not been addressed in detail. Namely, although cupels are indeed diagnostic of cupellation, there are several recipes for their manufacture, and their potential applications are also varied. This stresses the need for contextual analytical studies.

Against this background, this paper presents an archaeometric and historical study that started with the identification of a cupel in the assemblage excavated from the north side of Velotte Street, in the medieval Bourg Saint-Martin, Montbéliard. Of particular interest here is pit F7, a large feature extending over 30 square metres, which was only partly excavated. The filling material includes exceptionally abundant and varied artefacts, which indicated a date in the late $16^{\text {th }}$ or early $17^{\text {th }}$ century. The pit seems to have been rapidly abandoned after it had been dug out and filled up. However, this assemblage is mainly incomplete and fragmented, suggesting that this deposit is probably secondary. Together with the cupel discussed here, it is worth noting the presence of two probable fragments of ceramic alembics used for distillation ${ }^{1}$.

The cupel is a small vessel, with a diameter of $33 \mathrm{~mm}$ and the characteristic shape of an inverted truncated cone, about $13 \mathrm{~mm}$ thick in the centre and with a typical shal-

1. Details of the archaeological excavation and the assemblage are given in Cantrelle et al. (2000). A more extended description of the distillation equipment, and research on relevant historical records, can be found in Thomas et al. 2006.

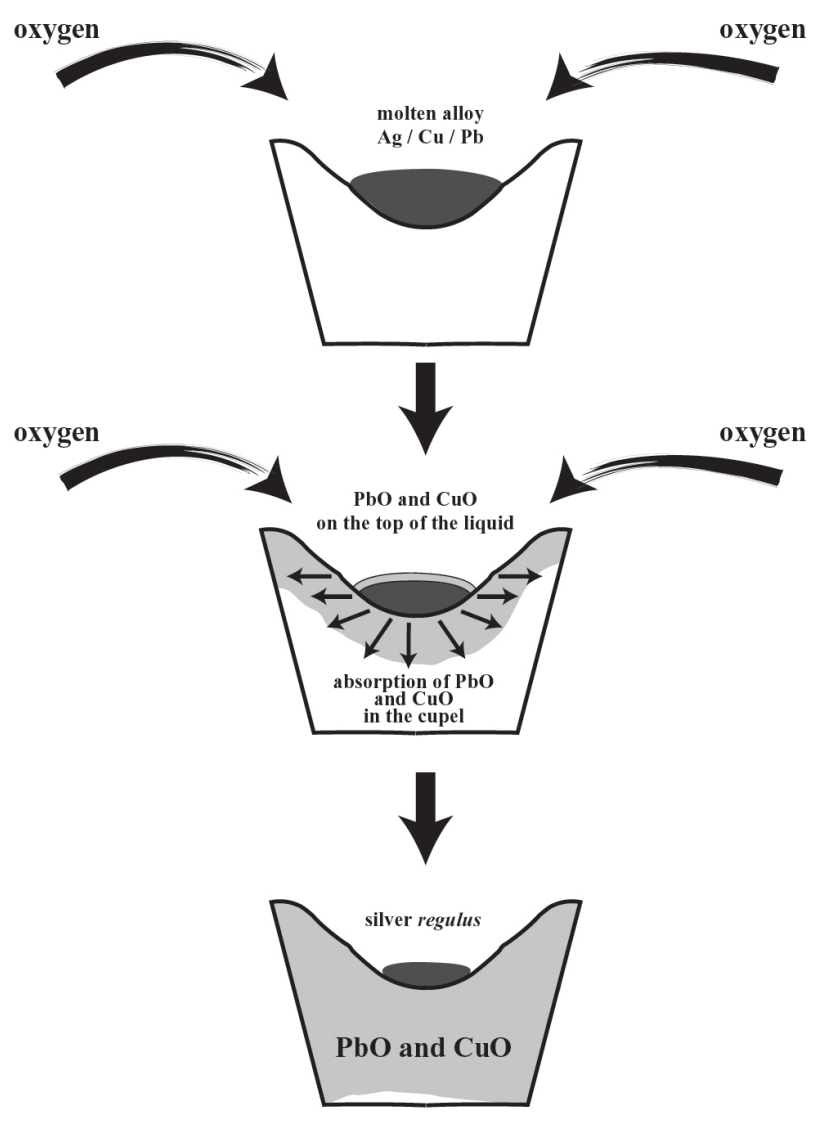

Figure 1 : Schematic drawing of the cupellation of a $\mathrm{Cu}-\mathrm{Ag}$ alloy with the addition of $\mathrm{Pb}$ in a bone ash cupel.

Figure 1 : Schéma de la coupellation d'un alliage Cu-Ag dans une coupelle de cendres, avec addition de plomb.

low concavity at the top, surrounded by a low rim (Fig. 2). Macroscopically, its fabric appears grey with white inclusions. Several black marks can be noticed on the outside surface, at the bottom and on the sides.

The analytical examination from this cupel will be used here to reconstruct its raw materials and interpret its use. In addition, comparison with relevant data of cupels from other sites, and a consideration of experimental studies, will allow some broader discussion about the manufacture and performance of cupels.

\section{Analytical Methodology}

The cupel sample was mounted as a standard cross section in epoxy resin and polished down to $1 \mu \mathrm{m}$ particle size. This specimen was first examined in a Leica DM LM reflected light optical microscope, and subsequently carbon coated for electron microscopy. 

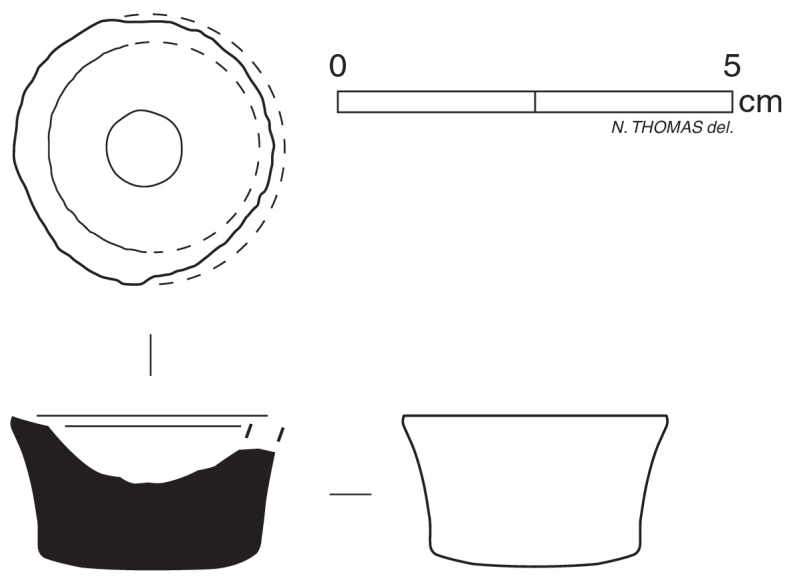

us238-F7

Figure 2: Line drawing of the cupel from Montbéliard.

Figure 2 : Dessin de la coupelle de Montbéliard.

Scanning electron microscopy was carried out using a Philips XL30 instrument, with an attached INCA Oxford energy dispersive spectrometer package. Operating conditions for data collection were as follows: working distance of $10 \mathrm{~mm}$; accelerating voltage of $20 \mathrm{kV}$; spot size of 5 (INCA conventional units) and process time 5 , corresponding to a detector deadtime of 30-40\%; and acquisition time of 75 seconds. Based on previous analyses, the lower confidence limits for this instrument may be established at $0.3 \mathrm{wt} \%$ for most compounds, and values below this limit should be taken as indicative only. In order to account for sample porosity and drift in beam intensity, all the SEM-EDS chemical data reported here have been normalised to $100 \%$ by weight (wt\%), and as stoichiometric oxides.

The same specimen was also analysed by polarising energydispersive X-ray fluorescence (ED-XRF), using a Spectro Xlab 2000 Pro instrument and an evaluation method optimised for alloys. Given that the specimen was not big enough to cover the detector window, ED-XRF results are not fully quantitative. However, this technique was particularly suited for the detection of those elements present in concentrations below the detection limits of the SEM-EDS system $(-0.1 \mathrm{wt} \%)$, with the XRF being sensitive down to about $10 \mathrm{ppm}$ for most elements.

\section{The UTILISATION OF THE CUPEL: ANALYSING, ASSAYING OR RECYCLING?}

As noted above, cupellation always involves the separation of noble metals from a larger metal melt. However, this ope- ration can take place in a relatively wide range of contexts and pursue different purposes. Cupellation could be used for ore assaying - i.e. the analysis of a small sample of an ore deposit to determine its richness in noble metals and thus guide subsequent mining -, for metal assaying - for example in a mint, to accurately establish alloy compositions to match a given standard, or in an alchemical laboratory, to check the purity of the metals -; but also for recycling - for instance, to retrieve the noble metals from scrap jewellery or debased coins (Bayley and Eckstein 1997; Rehren 1997; Bayley 2008). On this basis, clarifying the specific archaeological and technical purpose of cupellation remains often requires a careful consideration of the context, as well as an analytical approach.

\section{Microstructure and technical interpretation}

In the cross section of the Montbéliard cupel, a clear gradient in colour can be seen, from an orange and beige tinge at the top, through to dark grey and brown at the bottom

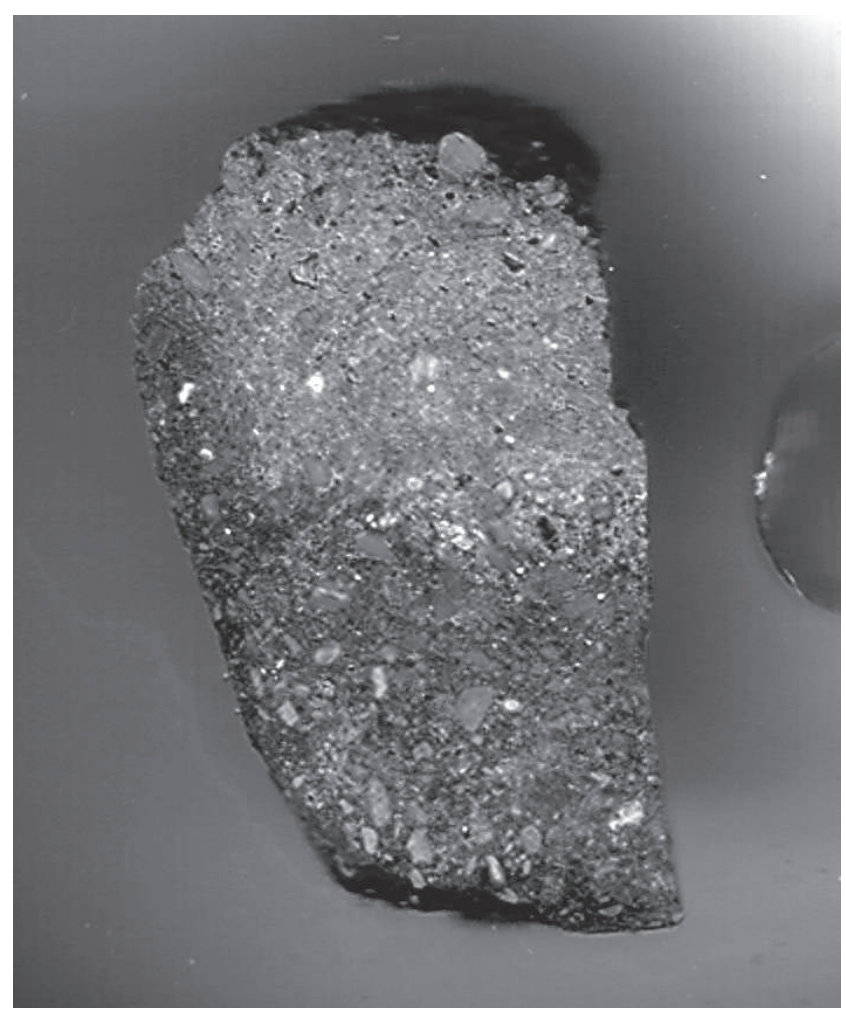

Figure 3: Polished cross section of the cupel mounted in epoxy resin. The maximum dimension of the sample is $13 \mathrm{~mm}$. Note the relative coarse grain size of some of the bone ash particles (grey, top).

Figure 3 : Lame épaisse polie, la plus grande dimension de l'échantillon est de $13 \mathrm{~mm}$. À remarquer les inclusions grossières d'os calciné (la partie grise correspond au sommet de la coupelle). 
(Fig. 3). Microscopic observation shows that the bulk of the fabric is now composed of lead oxide (or its secondary corrosion products, carbonates and hydroxides) very finely interspersed with minuscule bone ash grains (Figs. 4-5). The main distinct inclusions are relatively large fragments of bone ash, which never exceed $0.8 \mathrm{~mm}$ in diameter. Towards the bottom, also very small black phases were noticed, which are discussed later (section 4.2).

On average, $56 \mathrm{wt} \%$ of the cupel now comprises lead oxide, and $0.7 \mathrm{wt} \%$ is copper oxide (Table 1). In addition, the semi-quantitative ED-XRF analysis showed minor amounts of silver, zinc, antimony, arsenic and barium, in concentrations ranging from 400 to 900 parts per million $(0.04$ to $0.09 \mathrm{wt} \%)$. This contamination indicates that the cupel was used for refining silver whose main contaminant was copper. The presence of zinc, antimony and arsenic at a ratio of about one tenth to one twentieth of the copper content suggests that this argentiferous metal came from the smelting of an ore sample for assaying. After the smelting of the mineral sample in a crucible, the ore assay would culminate in the cupellation stage represented here. Conversely, this combination of trace elements is unlikely to come from scrap silver recycling or the analysis of coinage, given that circulating metals of this period would normally be much purer (see e.g. Rehren 1995). An alternative explanation would be that some of this contamination came with the added lead rather than with the copper alloy, but again this appears improbable, as assayers knew that the reliability of their results depended partly on the use of pure reagents (Boyvin 1639: f. 72), and we can expect pure lead to have

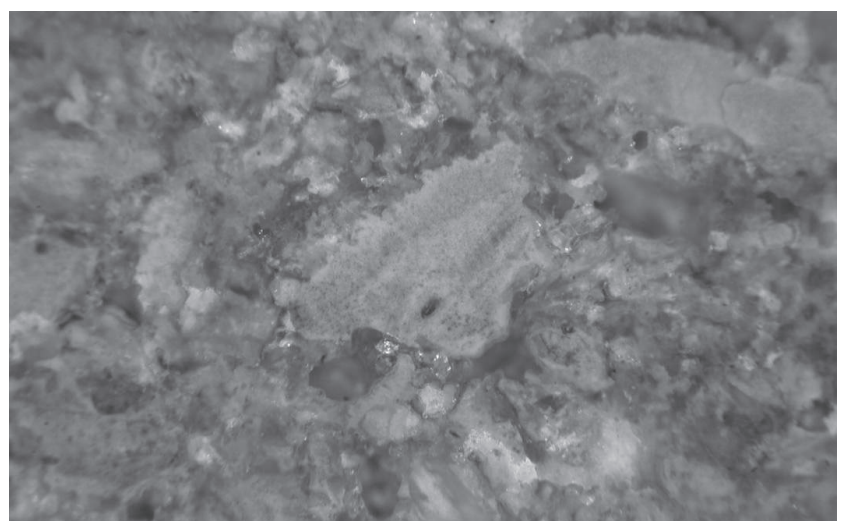

Figure 4: Photomicrograph of an area near the top of the cupel, showing fragments of bone ash of different sizes within a lead oxide-rich matrix (XPL, 50x magnification, long axis is $2 \mathrm{~mm}$ ). Figure 4 : Microphotographie de la partie supérieure de la coupelle montrant les fragments d'os calcinés de différentes dimensions dans une matrice riche en oxyde de plomb (lumière polarisée - analysée croisée, $50 x$, la longueur correspond à $2 \mathrm{~mm}$ ).

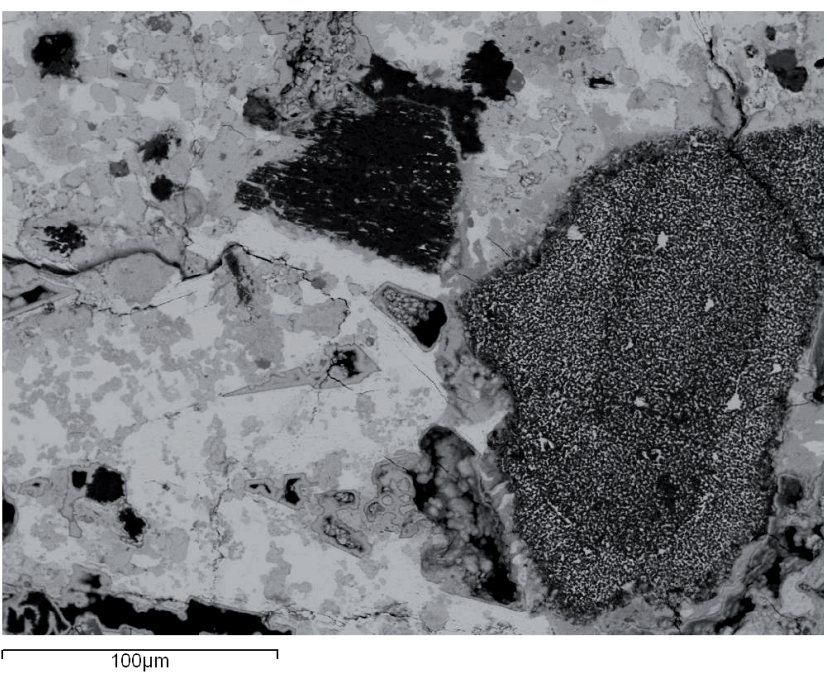

Figure 5: Backscattered electron micrograph of an area towards the top of the cupel. The general matrix is composed of almost pure lead oxide (light grey), finely interspersed with small fragments of bone ash soaked with up to $-70 \mathrm{wt} \%$ lead oxide (mid grey). The larger bone grain on the right contains $-30 \mathrm{wt} \%$ lead oxide, whereas the darker grain in the centre-top only absorbed a mere $3 \mathrm{wt} \%$ lead oxide, perhaps because it was not thoroughly calcined. Note the presence of globular corrosion products filling the porosities, following the leaching out of some phases (BSE, 400x).

Figure 5: Microscopie électronique, image en électrons rétrodiffusés de la partie supérieure de la coupelle. La matrice est composée d'oxyde de plomb presque pur (en gris clair), avec de petits fragments d'os calcinés finement dispersés et imbibés jusquà $70 \%$ en masse d'oxyde de plomb (gris moyen). Le plus gros grain d'os à droite contient environ $30 \%$ en masse d'oxyde de plomb, alors que le grain le plus sombre, en haut et au centre, a absorbé seulement $3 \%$ en masse d'oxyde de plomb, peut-être à cause d'une calcination incomplète. À remarquer des produits de corrosion globulaires remplissant la porosité crées par la lixiviation de certaines phases (BSE, 400x).

been easily available to the $17^{\text {th }}$-century assayer working in Montbéliard.

The bulk amount of silver left in the cupel is around $500 \mathrm{ppm}(0.05 \mathrm{wt} \%)$, as detected by ED-XRF, with some areas analysed by SEM-EDS reaching up to $0.5 \mathrm{wt} \%$. Some early assayers acknowledged that there is an unavoidable loss of silver into the vessel, and thus recommended keeping used cupels to retrieve it through re-smelting (Vigenere 1618: 8687; Clairand and Kind 2000: 94-95). However, the silver levels detected in the Montbéliard cupel are relatively high even by early modern standards - an aspect deserving further discussion.

A typical reason for the loss of silver into the cupellation matrix appears to be an insufficient $\mathrm{Pb} / \mathrm{Cu}$ ratio. Georg Agricola (Hoover and Hoover 1950: 251), among others, noted that the higher the concentration of copper in the sample to be assayed, the larger the amount of lead that 


\begin{tabular}{|c|c|c|c|c|c|c|c|c|c|c|c|}
\hline & $\mathrm{MgO}$ & $\mathrm{Al}_{2} \mathrm{O}_{3}$ & $\mathrm{SiO}_{2}$ & $\mathrm{P}_{2} \mathrm{O}_{5}$ & $\mathrm{Cl}$ & $\mathrm{K}_{2} \mathrm{O}$ & $\mathrm{CaO}$ & $\mathrm{MnO}$ & $\mathrm{FeO}$ & $\mathrm{CuO}$ & $\mathrm{PbO}$ \\
\hline area 1 & 0.3 & 0.4 & 1.1 & 18.0 & 1.4 & - & 21.3 & 0.1 & 0.3 & 0.9 & 56.2 \\
\hline area 2 & 0.2 & 0.1 & 1.6 & 18.5 & 1.4 & - & 25.1 & - & - & 0.7 & 52.7 \\
\hline area 3 & 0.4 & 0.2 & 2.0 & 16.6 & 0.7 & - & 29.4 & - & - & - & 50.8 \\
\hline area 4 & 0.6 & 1.2 & 4.3 & 11.4 & 0.5 & 0.5 & 26.9 & 0.4 & - & 0.6 & 53.9 \\
\hline area 5 & 1.4 & 1.4 & 4.4 & 10.8 & 0.4 & 0.2 & 23.8 & 0.3 & 0.4 & 0.9 & 56.1 \\
\hline area 6 & 1.4 & 1.3 & 3.3 & 12.6 & - & 0.7 & 24.5 & 0.7 & 0.5 & 0.9 & 54.0 \\
\hline area 7 & 1.7 & 1.2 & 3.6 & 9.4 & 0.3 & 0.1 & 20.7 & 0.6 & 1.0 & 1.0 & 60.7 \\
\hline area 8 & 0.9 & 1.2 & 3.7 & 9.3 & 0.3 & 0.1 & 20.8 & 0.2 & 1.3 & 0.8 & 61.5 \\
\hline Average & 0.9 & 0.9 & 3.0 & 13.3 & 0.6 & 0.2 & 24.0 & 0.3 & 0.4 & 0.7 & 55.7 \\
\hline Std. dev. & 0.56 & 0.54 & 1.25 & 3.81 & 0.51 & 0.25 & 3.10 & 0.25 & 0.49 & 0.32 & 3.73 \\
\hline Max. & 1.7 & 1.4 & 4.4 & 18.5 & 1.4 & 0.7 & 29.4 & 0.7 & 1.3 & 1.0 & 61.5 \\
\hline Min. & 0.2 & 0.1 & 1.1 & 9.3 & - & - & 20.7 & - & - & - & 50.8 \\
\hline
\end{tabular}

Table 1: Chemical composition by SEM-EDS, normalised to $100 \mathrm{wt} \%$, of eight successive 2.4 by $1.7 \mathrm{~mm}$ areas of the cupel scanning from top (area 1) to bottom (area 8). In addition to the compounds above, traces of soda were recorded in individual measurements of some smaller areas.

Tableau 1: Composition chimique par MEB-EDS, normalisée à $100 \%$, en \% massique, de huit surfaces de 2,4 sur 1,7 mm, depuis la partie supérieure (area 1) vers le bas de la coupelle (area 8). En plus des éléments mesurés ci-dessus, des traces de sodium ont été enregistrées lors d'analyses plus ponctuelles.

should be added to the cupel. There is a technical explanation for this: as noted by Bayley and Eckstein (2006: 152), if insufficient lead is present in the charge, part of the oxidised copper will be present as $\mathrm{Cu}_{2} \mathrm{O}$ rather than as $\mathrm{PbO} \cdot \mathrm{Cu}_{2} \mathrm{O}$. Unlike pure lead oxide or $\mathrm{PbO} \cdot \mathrm{Cu}_{2} \mathrm{O}$, a significant amount of silver can be dissolved in $\mathrm{Cu}_{2} \mathrm{O}$. Hence, a low $\mathrm{Pb} / \mathrm{Cu}$ ratio results in the formation of $\mathrm{Cu}_{2} \mathrm{O}$, which may carry silver down into the cupel body. This has been corroborated by the analyses of both cupellation hearth bottoms (i.e. the larger scale counterparts of cupels) (Bayley and Eckstein 2006) and experimentally made and used cupels (Téreygeol and Thomas 2003), where low $\mathrm{Pb} / \mathrm{Cu}$ ratios systematically resulted in higher silver losses. The $\mathrm{Cu}_{2} \mathrm{O}-\mathrm{PbO}$ phase diagram (Fig. 6) shows that, ideally, the $\mathrm{Pb} / \mathrm{Cu}$ ratio should be around 16 at least, to ensure the absence of free copper in the system (Riche and Gelis 1888: 156; Téreygeol and Thomas 2003).

However, it is clear that a low $\mathrm{Pb} / \mathrm{Cu}$ ratio was not the problem in the Montbéliard cupel. The average concentrations of $\mathrm{PbO}(55.7 \mathrm{wt} \%)$ and $\mathrm{CuO}(0.7 \mathrm{wt} \%)$ in the cupel can be recalculated by stoichiometry, resulting in an elemental $\mathrm{Pb} / \mathrm{Cu}$ ratio of $c a$. 80 , i.e. much higher than any of the recommended values ${ }^{2}$. An excessive amount of lead in the cupel also entailed some risks. Firstly, it would result

2. This is not to say that all of this lead would have been added at the cupellation stage. Most likely, some lead was present in the original ore assayed, and/or metallic lead could have been added to act as a collector for the noble metals during the smelting of the ore sample in a crucible. in a longer cupellation time, hence increasing the danger of silver losses through evaporation or by penetration into the cupel: a longer duration entailed higher risks of something going wrong. Secondly, as cupels have a limited volume and absorption capacity, a large amount of lead would mean reducing the weight of the $\mathrm{Ag}-\mathrm{Cu}$ alloy being assayed. For example, a cupel of the size discussed here would only be able to absorb $c a .20 \mathrm{~g}$ of metal oxides, thus the weight of the $\mathrm{Ag}-\mathrm{Cu}$ alloy assayed should have been $<2 \mathrm{~g}$ in order to ensure the minimum $\mathrm{Pb} / \mathrm{Cu}$ ratio of 16 .

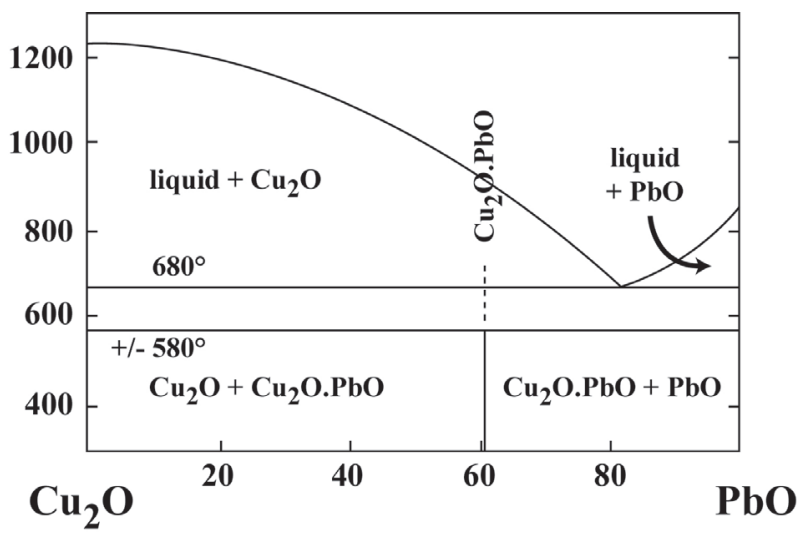

Figure 6: Phase equilibrium diagram of the $\mathrm{Cu}_{2} \mathrm{O}-\mathrm{PbO}$ system (after Gebhardt and Obrowski 1954).

Figure 6: Diagramme de phase du système $\mathrm{CU}_{2} \mathrm{O}-\mathrm{PbO}$. 
Even if silver losses were minimal, any quantitative inferences made on the basis of the assay of such a small sample could be severely biased. It may be assumed, however, that assayers would perform several tests of the same ore bodies in order to calculate the suitable ratios, account for possible errors and accommodate internal ore variability. Further aspects to be considered in explaining the silver losses would be the quality of the cupel - discussed below - and the skill of the assayer - which cannot be assessed from the information available.

All in all, the present study allows this cupel to be related to the assay of ores for their silver content. In this case, some silver was lost into the cupel, perhaps due to an excessive lead load. A survey of relevant historical sources supports this attribution.

\section{Metallurgy and assaying in Montbéliard: historical information ${ }^{3}$}

The mining district of Giromagny or Rosemont is situated about 30-40 kilometres to the north of Montbéliard, near Alsace, on an East-West line covering Lepuix-Gy, Giromagny and Auxelles. Local polymetallic deposits contain essentially ores of copper and argentiferious lead, which have been intensively exploited for silver since the beginnings of the $16^{\text {th }}$ century. Zinc is very frequently associated with galena, arsenopyrite and "grey copper" - a sulphosalt of copper usually containing arsenic and antimony (Thirion 1936). In addition, gangue minerals are primarily quartzitic, but they often contain barite - barium sulphate (Boulay 1984). Given the geographic proximity, and the detection of zinc, antimony, arsenic and barium in the cupel, it appears reasonable to hypothesise a link between the cupel found in Montbéliard and the mines at Giromagny.

Local historical data has allowed the identification of several potential users of a metallurgical laboratory where argentiferous ore from Giromagny could have been assayed. Towards the end of the $16^{\text {th }}$ century, a family of metallurgists and entrepreneurs called Morlot (or Morelot) built the Chagey smithy in the seigneury of Hericourt. This family was directly linked to the Giromagny mines through the marriage of one of the Morlots to the daughter of the mining magistrate of Alsace and Sundgau from 1570 to 1588. Although the Morlot family had their residence in SaintMartin square, and not on Velotte street, two men of this family married two sisters of the Virot family. The house of the latter lies metres away from pit F7, where the cupel was found. According to the written sources, the Virots were a

3. This is a brief summary of research detailed in Thomas et al. 2006. wealthy family of landowners who enjoyed substantial rents from their vast properties in the area. Hence, although the links are somewhat complex, both familial and entrepreneurial relations allow the archaeological cupel to be linked to local families and the mines in Giromagny.

A further character in this picture is Heinrich Schickhardt, an architect in charge of a building across the road from pit F7. Commissioned by Prince Frederic of Wurttemberg, Schickhard not only developed several estates, but also surveyed, described and sampled ore deposits in the Giromagny region on behalf of his patron. Some correspondence between the two relating to the description of argentiferous ore deposits bears witness to this. We do not know where Schickhardt lived, but there is the possibility he may have conducted assays on Velotte Street too. Schickhardt also wrote letters to Joseph Morlot, a blacksmith master of the aforementioned family, which reinforces the links between the three families, this location and their metallurgical endeavours.

Thus, there are at least three potential users for one single cupel, but it seems improbable that we will be able to confirm any of them. However, this information certainly supports the possibility of argentiferous ore being assayed in Bourg Saint-Martin.

\section{The manufacture AND PERFORMANCE OF CUPELS}

Historical alchemists, metallurgists and - more recently - chemists, have provided different recipes for making cupels. Most frequently, calcined bones and plants have been recommended as useful raw materials (cf. MartinónTorres et al. in press), although there are references to other materials such as calx (probably lime or calcite; Newman 1991: 597). In addition, historical sources (Berthier, 1834) and analyses of cupellation hearth bottoms (Bayley and Eckstein, 2006) have indicated the use of crushed shell, clay or limestone, either alone or mixed together. Since the Middle Ages, authors favoured the use of bone ash, as this material showed the best performance during cupellation. The bone ash had to be thoroughly washed to remove any organic matter, well sieved, and then pressed into a mould to obtain the desired shape.

According to some of these sources (e.g. Hoover and Hoover 1950: 228), ordinary potters would not normally make cupels, so users themselves had to produce them ${ }^{4}$. Furthermore, cupels are too fragile to be easily transported

4. This is also corroborated by the archaeological finds from Oberstockstall (Austria), where a lump of unused raw material for cupel making was found in the laboratory (Martinón-Torres, 2005: 160-171). 
long distances, and they could only be used once. Thus, the choice of different cupel-making materials could have been dictated, among other factors, by the availability of materials, time and economic constraints, adherence to an authoritative recipe, or actual knowledge of the properties of different materials. These social and cultural ramifications highlight the interest of technical studies of the manufacture and performance of archaeological cupels. The cupel from Montbéliard allows for some observations in this respect.

\section{Methodological considerations}

Determining the original raw materials of a cupel is not easy. The first difficulty is that, with very few exceptions (Martinón-Torres 2005: 160-171; White and Bayley forthcoming), cupellation remains found archaeologically are invariably used, i.e. 40 to $70 \%$ of their weight is now composed of lead oxide, which also constitutes the main structural component. The main reason for this is probably that unused cupels are too friable to be preserved in the archaeological record, and it is the absorbed lead oxide that acts as a consolidant and thus provides durability. In fact, when cupels were not fully penetrated by litharge during use, usually only the top part will be preserved - its thickness depending on the penetration depth of the litharge, and hence cupels typically show a rounded base.

Microscopic and X-ray diffraction analyses of cupel material may enable the identification of individual particles of bone, minerals, or other components, usually interspersed within the larger base metal oxides or secondary carbonates (see Figs. 4-5). However, these approaches do not allow for quantification, if several raw materials were mixed together. A further technical challenge stems from the scarcity of reference diffraction patterns for materials such as burnt calcite or wood ashes. In consequence, the most useful approach appears to be the study of chemical data, ideally combined with microscopy. We can obtain an indication of the original composition of a cupel prior to use by ignoring the contamination by lead and other base metal oxides, and re-normalising the chemical composition to $100 \%$.

The inorganic component of bone is known to be composed primarily of the mineral hydroxyapatite $\left[\mathrm{Ca}_{5}\left(\mathrm{PO}_{4}\right)_{3}(\mathrm{OH})\right](-85 \%)$, with small amounts of calcium carbonate $(-10 \%)$ and compounds of magnesium, sodium, fluorine and other elements also present $(-5 \%)$. Therefore, when the main constituents of the cupel material are the oxi-

As far as we are aware, there are no written records attesting to the existence of any workshop specialised in making cupels for trade. des of calcium and phosphorus, one can reasonably assume that the cupel was made of pure bone ash. This was the case of a cupel from Pymont (France) analysed by Rehren and Eckstein (2002), where $\mathrm{CaO}$ and $\mathrm{P}_{2} \mathrm{O}_{5}$ together accounted for almost $90 \mathrm{wt} \%$ of the original material of the cupel. The situation is more complicated when bone ash appears to be mixed with other materials, which we may term "additives" 5 . In these cases, a rough estimate of the additive composition can be made by calculating the weight ratio of calcium oxide to phosphate, and presuming that all of the phosphate in the cupel originates from bone. These calculations, however, will be based on two assumptions: firstly, that the additive would not have contained any major amounts of phosphorus - which is generally the case for calcite, clay and wood ashes -; and secondly, that the $\mathrm{CaO} / \mathrm{P}_{2} \mathrm{O}_{5}$ ratio in bone is relatively stable and predictable.

Regarding the second assumption, it has to be acknowledged that the bone $\mathrm{CaO} / \mathrm{P}_{2} \mathrm{O}_{5}$ ratio does vary: reported ratios for human bones vary from 1.26 (Tzaphlidou and Zaichick 2002) to 1.32 (Zaichick and Tzaphlidou 2002); in rats, these vary from 1.06 to 1.29 , depending on the part of the body, whilst remaining surprisingly consistent between different individuals; known ratios for rabbit bones are 0.78 and 1.06 , and the ratio for sheep is 0.82 (Tzaphlidou et al. 2004). In archaeological examples, analyses of medieval bone-ash lined cooking pots have yielded a ratio of 1.15 (Keller and Stern 1999), while this value for the Pymont cupel was 1.07 (Rehren and Eckstein 2002) ${ }^{6}$. Our unpublished analyses of an experimental cupel made with industrial bone ash and used for silver refining yielded values ranging from 1.40 to 1.60 .

Further technical limitations should be mentioned: calcium and phosphorus are precisely some of the elements more susceptible of post-depositional alteration in archaeological materials (Freestone 2001; Schwedt et al. 2004) - which highlights the convenience of combining chemical with microscopic information. Another problem is that ZAF correction procedures in standard analytical equipment may not be calibrated for such high-lead matrices as used cupels. Significantly, in our experimental cupel mentioned above, higher $\mathrm{CaO} / \mathrm{P}_{2} \mathrm{O}_{5}$ ratios were systematically detected in

5. We are using the term "additive" instead of "binder" in an attempt to find a less interpretative denomination: this additive could increase the bulk amount of raw material, function as a binder, or be added for several other cultural or economic reasons - see discussion below.

6. In most publications, these values are reported as average $\mathrm{Ca} / \mathrm{P}$ ratios or elemental compositions after several measurements, which we have transformed into oxide ratios by stoichiometric calculation. We are not reproducing standard deviations because that degree of precision is not necessary here, given the unavoidably "coarse" nature of our calculations. 
those regions with higher $\mathrm{PbO}$ concentrations - most likely an analytical artefact, but it needs to be clarified.

Despite these problems, and while bearing in mind that our estimates cannot be fully quantitative, some calculations can be performed. We begin by assuming a nominal $\mathrm{CaO} / \mathrm{P}_{2} \mathrm{O}_{5}$ ratio in bone of 1.2 , and that all of the $\mathrm{P}_{2} \mathrm{O}_{5}$ in the cupels is due to the bone ash. Thus, by multiplying the $\mathrm{P}_{2} \mathrm{O}_{5}$ weight in the cupels by 1.2 , we obtained an estimate of the amount of $\mathrm{CaO}$ that the bone ash would contain. We can now label those components as "bone", and isolate them in the compositional data. The remainder will be the "additive" 7 .

\section{The case of Montbéliard}

Several measurements of the chemical composition of the Montbéliard cupel were obtained by analysing a series of 2.4 by $1.7 \mathrm{~mm}$ areas from top to bottom of the cross-section by SEM-EDS (Table 1). When the calculations detailed above are performed on the data, an interesting pattern emerges (Table 2, Fig. 7). While the top surface of the vessel is virtually pure bone ash, with less than $10 \mathrm{wt} \%$ of "additive", the bone to additive ratio decreases to approximately $1: 1$ in the body of the cupel. This extra material was probably wood ash, or perhaps a mixture of clay and other finely crushed calcareous material, explaining the remainder silica, lime and other light elements in the bulk chemical composition (Table 2). In other words, it would seem that the maker of this cupel used a mixture of one part of bone ash to one part of additive for the bulk of the vessel, but then applied a layer of purer bone ash on the top.

Why would someone do that? What would be the performance characteristics of such a cupel? The answer to the first question can be hypothesised on the basis of our own experience of making and using cupels. Previously, we assumed that the additive would function as a binder or cement, facilitating the manufacture of the vessels (Martinón-Torres and Rehren 2005). However, experience has taught us that it is relatively easy to manufacture pure bone ash cupels too, simply using water to make the paste and then leaving them to dry thoroughly. Conversely, what our experiments made obvious is that producing the bone ash to start with is a timeand labour-consuming job. Removing flesh and marrow from the bones, burning them in a relatively clean environment, crushing and grinding, and repeatedly washing and sieving, are tedious tasks producing a fairly small volume of bone ash. It therefore appears sensible that, even if not necessary as a

7. For a more detailed explanation of these calculations, and practical examples with several cupels, see Martinón-Torres et al. in press.

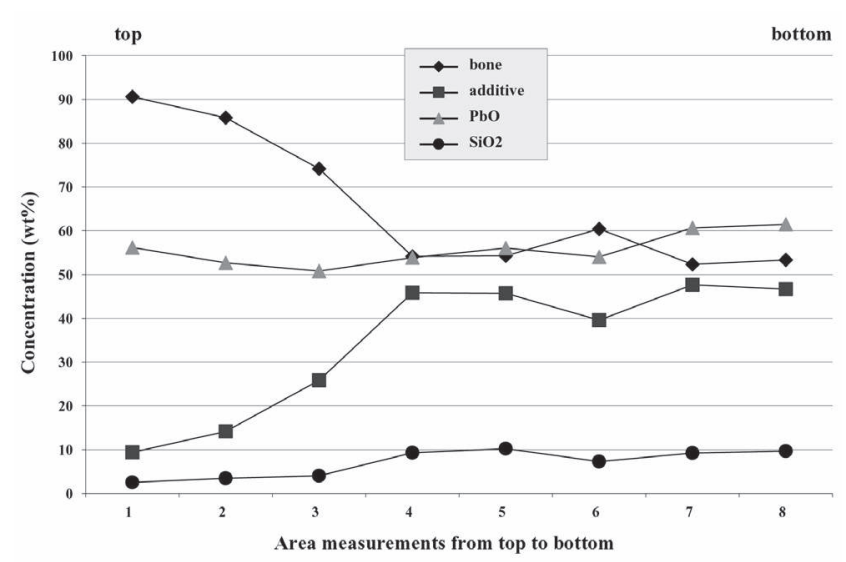

Figure 7: Line chart comparing the ratio of bone ash to additive, and their correlation with lead oxide and silica, throughout the cupel. Data for "bone" was obtained based on a bone $\mathrm{CaO} /$ $\mathrm{P}_{2} \mathrm{O}_{5}$ ratio of 1.2:1, and compositional information from Table 2. Accordingly, the "additive" content was calculated by removing all the $\mathrm{P}_{2} \mathrm{O}_{5}$ and reducing the total $\mathrm{CaO}$ content by 1.2 times the weight of $\mathrm{P}_{2} \mathrm{O}_{5}$ (see Martinón-Torres et al. in press). Note the significant decrease in bone content from the third area downwards ( $-5 \mathrm{~mm}$ from the top), the positive correlation between $\mathrm{PbO}$ (from Table 1) and $\mathrm{SiO}_{2}$ (from Table 2), and the negative correlation between bone and $\mathrm{SiO}_{2}$.

Figure 7 : Graphique comparant les rapports de la cendre d'os et de l'élément ajouté dans chaque partie de la coupelle, et leur corrélation avec l'oxyde de plomb et la silice. Les données pour l'os calciné ont été obtenues à partir d'un rapport $\mathrm{CaO} / \mathrm{P}_{2} \mathrm{O}_{5}$ de 1,2 pour 1, et les données du tableau 2. En conséquence, la part de l'excipient est calculée en enlevant lz totalité de $\mathrm{P}_{2} \mathrm{O}_{5}$ et en retranchant le $\mathrm{CaO}$ correspondant à 1,2 fois la masse de $\mathrm{P}_{2} \mathrm{O}_{5}$. $\grave{A}$ remarquer la diminution significative de la part de l'os calciné à partir de la troisième zone (à $5 \mathrm{~mm}$ environ depuis le sommet), la corrélation positive entre $\mathrm{PbO}$ (du tableau 1) et $\mathrm{SiO}_{2}$ (du tableau 2), et la corrélation négative entre l'os et $\mathrm{SiO}_{2}$.

cement, wood ash or other additives such as clay would have been added to increase the bulk volume of the cupel-making material. In what could be a similar scenario, late $19^{\text {th }}$ century coin minters at the Paris Mint used cupels made of a mixture of bone and wood ash, admittedly due to economic reasons, though acknowledging that pure bone ash worked better (Riche and Gelis 1888: 50).

Regarding the performance of cupels not made of pure bone ash, there is no doubt that siliceous materials are unsuitable for cupellation because, at high temperatures, lead oxide readily reacts with silica to form viscous lead silicates, which impede the absorption into the cupel matrix and hamper a neat separation of the noble metal bead. This would probably be a limitation of cupels made by mixing bone ash with clay. This point is more difficult to demonstrate when silica is only present in comparatively small 


\begin{tabular}{|c|c|c|c|c|c|c|c|c|c|c|}
\hline & $\mathrm{MgO}$ & $\mathrm{Al}_{2} \mathrm{O}_{3}$ & $\mathrm{SiO}_{2}$ & $\mathrm{P}_{2} \mathrm{O}_{5}$ & $\mathrm{Cl}$ & $\mathrm{K}_{2} \mathrm{O}$ & $\mathrm{CaO}$ & $\mathrm{MnO}$ & $\mathrm{FeO}$ & $\mathrm{Total}$ \\
\hline area 1 & 0.8 & 0.8 & 2.5 & 42.0 & 3.2 & - & 49.6 & 0.3 & 0.7 & 42.9 \\
\hline area 2 & 0.4 & 0.3 & 3.5 & 39.4 & 3.0 & - & 53.5 & - & - \\
\hline area 3 & 0.9 & 0.4 & 4.0 & 33.6 & 1.5 & - & 59.5 & - & - & 46.9 \\
\hline area 4 & 1.3 & 2.6 & 9.3 & 24.8 & 1.2 & 1.0 & 58.8 & 0.9 & - & 45.7 \\
\hline area 5 & 3.3 & 3.2 & 10.2 & 25.2 & 0.8 & 0.4 & 55.2 & 0.7 & 1.0 & 43.0 \\
\hline area 6 & 3.1 & 3.0 & 7.3 & 28.0 & 0.1 & 1.5 & 54.4 & 1.5 & 1.1 & 45.0 \\
\hline area 7 & 4.3 & 3.2 & 9.2 & 24.4 & 0.8 & 0.2 & 53.8 & 1.5 & 2.6 & 38.4 \\
\hline area 8 & 2.5 & 3.1 & 9.7 & 24.7 & 0.7 & 0.3 & 55.0 & 0.5 & 3.5 & 37.8 \\
\hline
\end{tabular}

Table 2. Re-calculated composition of the original cupel matrix. The figures were obtained by ignoring the $\mathrm{PbO}$ and $\mathrm{CuO}$ contents of the cupel and re-normalising the remaining concentrations to $100 \mathrm{wt} \%$. Column 'Total' gives the original total wt $\%$ of these compounds (MgO to $\mathrm{FeO}$ ) in the sample areas prior to re-normalisation. The bottom rows ( 4 to 8 ) show significant concentrations of compounds other than $\mathrm{P}_{2} \mathrm{O}_{5}$ and $\mathrm{CaO}$, as well as a higher $\mathrm{CaO}: \mathrm{P}_{2} \mathrm{O}_{5}$ ratio, indicating the presence of a lime- and silica-rich additive mixed with the bone ash.

Tableau 2 : Composition chimique de la coupelle avant utilisation, recalculée. Les données ont été obtenues en écartant les concentrations en PbO et $\mathrm{CuO}$, et en normalisant le total à $100 \%$. La colonne " total " correspond à la concentration en \% massique des éléments restants (de MgO à $\mathrm{FeO}$ ) et avant normalisation à $100 \%$. Les parties les plus proches du bas de la coupelle montrent des concentrations significatives en des éléments autres que $\mathrm{P}_{2} \mathrm{O}_{5}$ et $\mathrm{CaO}$, de même qu'un rapport élevé de $\mathrm{CaO} / \mathrm{P}_{2} \mathrm{O}_{5}$ indiquant la présence d'un excipient riche en $\mathrm{CaO}$ et $\mathrm{SiO}{ }_{2}$ mélangé à de la cendre d'os.

concentrations, as would be the case in most wood ashes. In his study of cupels from Oberstockstall, which also contained bone mixed with of wood ash ${ }^{8}$, Rehren (1998) showed that bone apatite becomes unstable in the presence of silica, reacting with the lead oxide to dissolve and recrystallise as complex calcium silica phosphates, and in so doing clogging up the porosity needed to mechanically absorb the liquid lead oxide (see also Bayley and Eckstein 2006). Similar crystals were found in the Montbéliard cupel, visible as small black phases (see figs. 8-9). The users possibly noticed the practical problems of silica-rich cupellation matrices, and this would explain the application of the purer top facing, which is noticed in this example from Montbéliard and also in those from Oberstockstall (Martinón-Torres 2005: 160-171). In this manner, even if the absorption capability of the cupel was reduced, the assayers could ensure a good separation of the silver bead.

With this background, the crucial need for very pure bone ash for the whole cupel, as emphasised by many authors, appears difficult to justify in purely technical terms. Was the use of additives really compromising the efficiency of the cupels? Or was it rather a cost-effective solution to the scarcity of bone ash? In Oberstockstall, those cupels richer in silica appeared to have absorbed less lead oxide, suggesting a more limited absorption capability (Rehren

8. In previous publications (Rehren 1998; Martinón-Torres and Rehren 2005), a miscalculation led to the erroneous interpretation of the "additive" mixed with the bone ash in the Oberstockstall cupels as clay. However, it is more likely that this additive was in fact wood ash (Martinón-Torres et al., in press).
1998; Martinón-Torres and Rehren 2005). However, the Montbéliard cupel shows comparable levels of lead oxide in both the pure and debased layers - and a positive correlation between silica and lead oxide (fig. 7) that probably reflects the preferential reaction between the two, compared to the mechanical absorption of lead oxide in the porous bone ash structure (figs. 8-9).

Clearly, in order to compare the absorption capability of different cupel materials, it is necessary to experiment with known mixtures, and then analyse the concentrations of absorbed lead oxide in a standardised manner. The existing analytical data appears too heterogeneous to allow any reliable comparison. Both the cupels from Oberstockstall and Pymont, analysed by ICP-AES, show high lead oxide values, between 60 and $70 \mathrm{wt} \%$. In our experimental study, we saturated a pure bone ash cupel until it leaked, but the SEM-EDS area analyses only reached an average $52 \mathrm{wt} \%$ $\mathrm{PbO}$, comparable to the $55 \mathrm{wt} \% \mathrm{PbO}$ of the wood-rich, supposedly less efficient, Montbéliard cupel. Spot analyses on both cupels, however, showed highly variable $\mathrm{PbO}$ values ranging from 5 to $80 \mathrm{wt} \%$, again highlighting the need for standard analytical protocols. The SEM-EDS analysis of a wide range of cupellation hearth bottoms, made with different mixtures of raw materials, showed base metal oxide concentrations between 55 and $90 \mathrm{wt} \%$, and led to the conclusion that "there is no correlation between the composition of the hearth lining and the effectiveness of the cupellation process" (Bayley and Eckstein 2006: 152).

In this context, it becomes important to reflect on the words 'effectiveness' and 'efficiency'. An effective cupel is that 


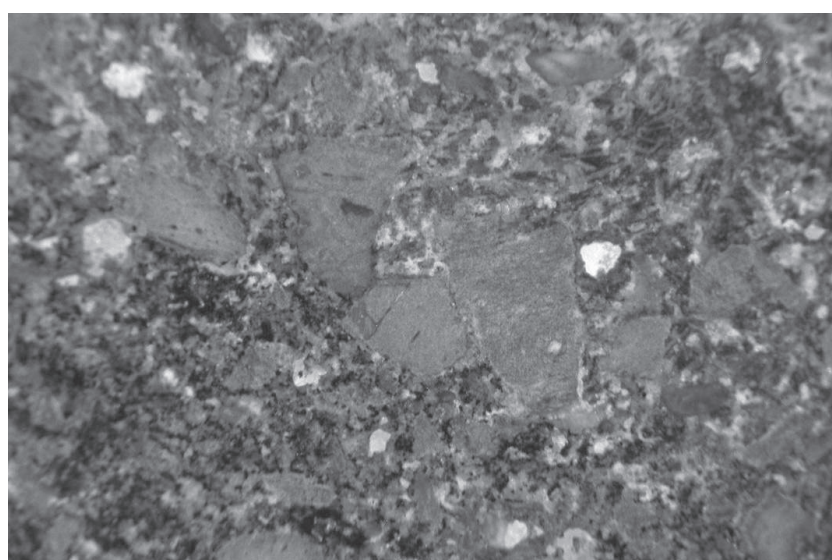

Figure 8: Photomicrograph of the cupel fabric towards the bottom of the cupel, showing fragments of bone ash of different sizes within a lead oxide-rich matrix, and a darker colour resulting from the abundance of small black calcium silica phosphates (XPL, 50x magnification, long axis is $2 \mathrm{~mm}$ ).

Figure 8: Microphotographie de la partie inférieure de la coupelle montrant les fragments d'os calcinés de différentes dimensions dans une matrice riche en oxyde de plomb. La couleur sombre est due à l'abondance de petites inclusions noires de phosphates de calcium et de silicium (lumière polarisée - analyse croisée, 50x, la longueur correspond à $2 \mathrm{~mm}$.

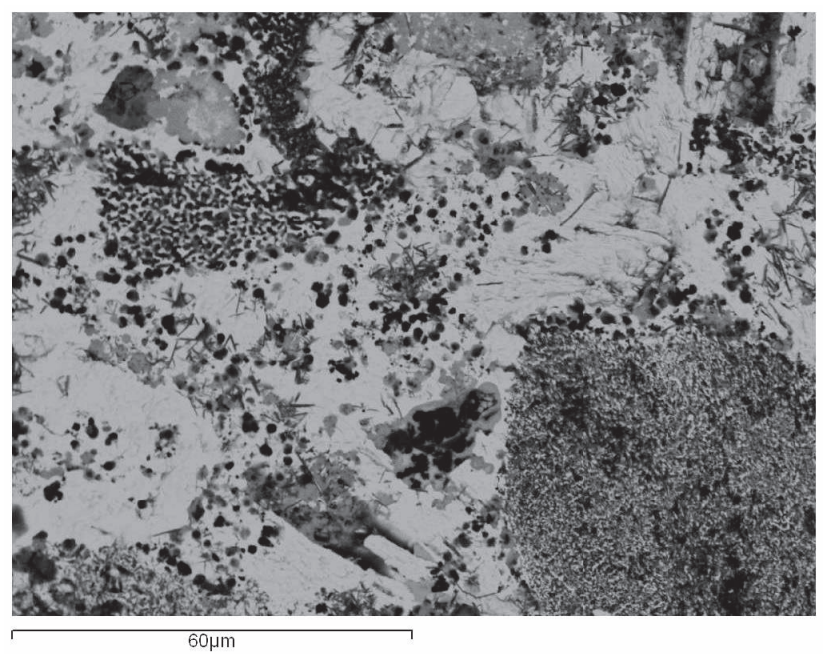

Figure 9: Backscattered electron micrograph of an area towards the base of the cupel. Note the overall abundance of litharge (light grey), the particles of bone ash (mid grey), and the clusters of small calcium-silica phosphates (black phases), resulting from the decomposition of bone apatite in the presence of silica (BSE, 1000x).

Figure 9: Microscopie électronique, image en électrons rétrodiffusés de la partie inférieure de la coupelle. À remarquer l'abondance de la litharge (en gris clair), les inclusions d'os calciné (gris moyen), et les grappes de petites inclusions de phosphates de calcium et de silicium (en noir), résultant de la décomposition de l'apatite de l'os en présence de silice (BSE, 1000x). which accomplishes the intended job; an efficient one is that which does so with the minimum expenditure of time and effort. When talking about efficiency, we need to consider specific factors affecting each context, such as the availability of specific materials or skills, which cannot be accessed through materials analyses alone. Which parameters are we considering when assessing the efficiency of a cupel? Clearly, a high capacity for absorbing liquid lead oxide is a major consideration: higher absorption means a larger sample and hence potentially higher accuracy and precision of the assay. However, this can easily be achieved by using a larger cupel as long as a sufficient capillary action is drawing the lead oxide into the body of the cupel. A higher percentage of lead oxide within the used cupel on its own is not necessarily denoting a better or more effective process. An obvious crucial issue is to avoid cracks through which liquid metal could seep into the body of the cupel, resulting in a smaller silver bead at the end of the process. A suitable additive may improve the drying properties of the cupel, and reduce the risk of cracks forming. Another important aspect is the ease with which the typically small silver bead can coalesce and then be removed from the cupel. Clean and easy separation is probably facilitated by pure bone ash, while a siliceous component, producing a larger amount of vitreous material, will probably result in a more 'sticky' top surface and either slag adhering to the bead, or loss of some silver to the surface. This could be the reason behind the final dusting of fine bone ash to the top surface of a good cupel, effectively separating the diluted body with its additive from the silver bead. Similarly, the central depression clearly facilitates the coalescence of all the silver into a single bead. There may be other factors more relevant to the medieval and post-medieval assayers than the final percentage of lead oxide in the used cupel.

Only a thorough study of the material properties and performance characteristics of different cupellation media will improve our understanding of the possible reasons behind the choices made by the craftspeople. For example, not only do several authors talk about bone and wood, but they also specify their preferred species and parts - did this have any practical effect? Likewise, would different burning temperatures have a significant impact in the resulting quality of the cupel raw materials?

\section{SUMMARY AND CONCLUSIONS}

The present study has furnished information on one episode of the metallurgical history of Montbéliard, but also raised questions for future studies. We would like to finish this paper by emphasising three main points: 
Firstly, the analytical data shows that the cupel was moulded from a mixture of bone ash and a lime-rich additive, with a top layer of pure bone ash, and was subsequently used for the assay of an argentiferous copper-based ore sample. Possibly, an excessively high lead to copper ratio - and not the use of wood ash as an additive - was the cause of a significant loss of silver into the cupel. The historical record indicates that this cupellation event is most likely related to families who lived in Bourg Saint-Martin and had metallurgical interests in the nearby Giromagny mines.

Secondly, reliable comparisons within and between sites require the use of standardised analytical methods. For the study of cupel manufacture, we have argued that microscopy and microanalysis - combining spot and area measurements - constitute the most useful methodological strategy (Martinón-Torres et al. in press). In addition, systematic experimental work is needed in order to assess the manufacturing requirements, material properties and performance of different raw materials.

Thirdly, this paper highlights the importance of contextual analytical studies of metallurgical remains. Besides providing details of the history of a particular site, these focused approaches illustrate aspects of the understanding of the properties of different materials, individual choices and practical solutions that often differ from the written recipes given in authoritative texts. The potentials of combining and contrasting textual and archaeometric information are vast, and we eagerly expect more work along these lines.

\section{Acknowledgements}

We would like to express our thanks to Bernard Fauchille, director of the Montbéliard Museum, for his permission to conduct analyses of the cupel, and to Corinne Goy (Inrap) and Hélène Grimaud (Montbéliard archaeological service), for their valuable help in facilitating our access to the assemblage. The analyses were carried out at the Wolfson Archaeological Science Laboratories of the UCL Institute of Archaeology in London. Many thanks are due to Simon Groom, Kevin Reeves and Xander Veldhuijzen for their technical assistance. We are also grateful to Marriet White and Justine Bayley for their comments, and for allowing us to cite their unpublished report.

\section{References}

BaYley, J., 1991. Processes in precious metal working, in P. Budd, B. Chapman, C. Jackson, R. Janaway, and B. Ottaway (eds), Archaeological Sciences 1989. Proceedings of a Conference on the Application of Scientific Techniques to Archaeology, Bradford, September 1989, 125-131. Oxford: Oxbow.

BAYLEY, J., 2008. Medieval precious metal refining: archaeology and contemporary texts compared, in M. Martinón-Torres and Th. Rehren (eds), Archaeology, History and Science: Integrating Approaches to Ancient Materials (UCL Institute of Archaeology Publications), 131-150. Walnut Creek: Left Coast Press.

Bayley, J. and Eckstein, K., 1997. Silver refining - production, recycling, assaying, in A. Sinclair, E. A. Slater, and J. Gowlett (eds), Archaeological Sciences 1995. Proceedings of a Conference on the Application of Scientific Techniques to the Study of Archaeology (Liverpool, July 1995), 107-111. (Oxbow Monographs 64). Oxford: Oxbow.

Bayley, J. and Eckstein, K., 2006. Roman and medieval litharge cakes: structure and composition, in J. Pérez-Arantegui (ed), Proceedings of the 34th International Symposium on Archaeometry, Zaragoza, 3-7 May 2004, 145-153. Zaragoza: Institución Fernando el Católico, CSIC [http://www.dpz.es/ ifc/libros/ebook2621.pdf].

Berthier, P., 1834. Traité des essais par la voie sèche, ou, Des propriétés, de la composition et de l'essai des substances métalliques et des combustibles. Paris: Thomine.

Boulay, C., 1984. Étude de filons métalliferes (Cu, Pb, Zn, F, Ba) à gangue d'anhydrite silicifiée des régions de Giromagny, Auxelles et Sewen-Urbès (Vosges du sud-est, France). Thesis, Institut national polytechnique de Lorraine.

Boyvin, J., 1639. Traité des monnoies, pratique et fabrication d'icelles pour l'instruction d'un maistre général des monnoies. Bibliothèque municipale de Besançon, ms.939.

Cantrelle, S., Goy, C., and Munier, C. (eds), 2000. Histoire d'un quartier de Montbéliard (Doubs). Le bourg Saint-Martin (XII'-XX siècle). (Documents d'Archéologie Française, 83). Paris: MSH.

Clairand, A. and KInd, J.-Y., 2000. Le traité des monnaies de Jean Boizard d'après l'édition de Paris de 1692 (Documents d'Histoire Monétaire, Sources imprimées; 1) Paris: K\&C.

Freestone, I. C., 2001. Post-depositional changes in archaeological ceramics and glasses, in D. R. Brothwell and A. M. Pollard (eds), Handbook of Archaeological Sciences, 615-625. Chichester, New York, Weinheim, Brisbane, Singapore and Toronto: John Wiley \& Sons Ltd.

Gebhardt, E. and Oвrowsкi, W., 1954. Über den Aufban des Systems Kupfer-Blei-Saürstoff. Zeitschrift für Metallkunde, 45, 332-341.

Hoover, H. C. and Hoover, H. L., 1950. Georgius Agricola: De Re Metallica. Translated from the First Latin Edition of 1556. 
(rep. edn. of the 1912 edn., London, The Mining Magazine). New York: Dover Publications Inc.

Keller, C. and STERN, W. B., 1999. Rückstände in Kochgefässen - Zum Phänomen der Knochenasche, Jahrbuch des Oberösterreichischen Musealvereins, 1999, 129-146.

Martinón-Torres, M., 2005. Chymistry and crucibles in the Renaissance laboratory: an archaeometric and historical study. $\mathrm{PhD}$ thesis, University of London.

Martinón-Torres, M. and Rehren, Th., 2005. Ceramic materials in fire assay practices: a case study of 16th-century laboratory equipment, in M. I. Prudencio, M. I. Dias, and J. C. Waerenborgh (eds), Understanding People through their Pottery. Proceedings of the 7th European Meeting on Ancient Ceramics (EMAC '03), Lisbon 2003, 139-149. Lisbon: Instituto Portugues de Arqueologia.

Martinón-Torres, M., Rehren, Th., Thomas, N. and Mongiatti, A., in press. Identifying materials, recipes and choices: some suggestions for the study of archaeological cupels, in A. Giumlia-Mair et al. (eds), Archaeometallurgy in Europe. Proceedings of the II International Conference. Milan: Associacione Italiana de Metalurgia.

Newman, W. R., 1991. The Summa Perfectionis of Pseudo-Geber; a Critical Edition, Translation, and Study. (Collection de travaux de l'Académie internationale d'histoire des sciences, XXXV). Leiden; New York; København; Köln: E. J. Brill.

Rehren, Th., 1995. Kupfer vom Tor zur Welt, in S. Lux and R. Althoff (eds), Kissipenny und Manilla. Begleitband zur Ausstellung im Kultur- und Stadthistorischen Museum der Stadt Duisburg, 20. Mai bis 13. August 1995, 59-64. Duisburg.

Rehren, Th., 1997. Metal analysis in the Middle Ages, in G. de Boe and F. Verhaeghe (eds), Material Culture in Medieval Europe: Papers of the 'Medieval Europe Brugge 1997' Conference, vol. 7, 9-15. Zellik: Instituut voor het Archeologisch Patrimonium.

Rehren, Th., 1998. Kontext und Analyse der Aschkupellen von Oberstockstall, in S. von Osten (ed), Das Alchemistenlaboratorium von Oberstockstall. Ein Fundkomplex des 16. Jahrhunderts aus Niederösterreich, 333-348. (Monographien zur Frühgeschichte und Mittelalterarchäologie 6). Innsbruck: Universitätverlag Wagner.

Rehren, Th. and Eckstein, K., 2002. The development of analytical cupellation in the Middle Ages, in E. Jerem and
K. T. Biró (eds), Archaeometry 98. Proceedings of the 31st Symposium, Budapest, April 26-May 3 1998, vol. 2, 445-448. (BAR International Series 1043 - Central European Series 1). Oxford: Archaeolingua.

Rehren, Th. and Klappauf, L., 1995. ... ut oleum aquis - Vom Schwimmen des Silbers auf Bleiglätte, Metalla, 2, 19-28.

Riche, A. and Gelis, E., 1888. L'art de l'essayeur. Paris: Baillière et fils.

Schwedt, A., Mommsen, H., and Zacharias, N., 2004. Postdepositional elemental alterations in pottery: neutron activation analyses on surface and core samples, Archaeometry, 46, 85-101.

Téreygeol, F. and Thomas, N., 2003. La coupellation des alliages cuivre-argent : Approche expérimentale de l'essai d'argent par voie sèche, Revue d'Archéométrie, 27, 171-181.

Thirion, C., 1936. Les gîtes métallifères des Vosges (Vosges hercyniennes), Revue industrielle, 141-151.

Thomas, N., Martinón-Torres, M., Goy, C., and Rehren, Th., 2006. La fouille archéologique du quartier Velotte à Montbéliard: nouvelles données sur des opérations de chimie oubliées, Bulletin de la Société d'émulation de Montbéliard, 129, 441-465.

Tzaphlidou, M., Speller, R., Royle, G., and Griffiths, J., 2004. High resolution $\mathrm{Ca} / \mathrm{P}$ maps of bone architecture, Nuclear Science Symposium Conference Record. 2004 IEEE, 5, 32673270 .

Tzaphlidou, M. and Zaichick, V., 2002. Neutron activation analysis of calcium/phosphorus ratio in rib bone of healthy humans, Applied Radiation and Isotopes, 57, 779-783.

Vigenere, B., 1618. Traicté $d u$ Feu et du Sel, Excellent et rare Opuscule du sieur Blaise de Vigenère, Bourbonnois, trouvé parmy ses papiers après son décés. Paris: Abel l'Angelier.

White, H. and Bayley, J., forthcoming, Tower of London: Analytical investigations of bone-ash cupels. RD Report. Portsmouth: English Heritage.

Zaichick, V. and Tzaphlidou, M., 2002. Determination of calcium, phosphorus, and the calcium/phosphorus ratio in cortical bone from the human femoral neck by neutron activation analysis, Applied Radiation and Isotopes, 56, 781-786. 